\title{
In-Vitro Anticancer and Antioxidant Activities of Eremina desertorum (Forsskal, 1775) Snail Mucin
}

\author{
Shimaa Attia Atta ${ }^{1 *}$, Amina Mohamed Ibrahim ${ }^{2}$, Fayed Attia Koutb Megahed ${ }^{3}$
}

\begin{abstract}
Objectives: The aim of the present research is to elucidate the anti-oxidant and anti-tumor activities of the mucin extracted from Ereminia desertorum snails' mucus against two types of tumor cell lines; human colon adenocarcinoma (CACO-2) cells and human hepatoma (HepG-2) cells. Methods: Both cell lines were treated with Ereminia desertorum snails' mucin and the oxidative markers were measured in culture media and cells by biochemical and gene expression analysis using RT-PCR. The tumor suppressor gene expression was also evaluated using RT-PCR. Results: The culture media of HepG-2 or CACO-2 cells treated with the extract have high significant increased levels of catalase, SOD, GSH and total antioxidants. Apart from SOD in CACO-2 cells that didn't differ from untreated cells. Also, Gene expression

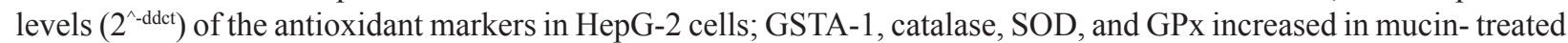
cells. Also, these antioxidant genetic markers were up-regulated in CACO-2 cells by treatment with mucin extract. Gene expression levels ( $2^{\wedge}$-ddct $)$ of tumor suppression genes (p53, Rb, APC, and PTEN) in both HepG-2 and CaCO-2 cells were increased in mucin extract-treated cells. Conclusion: The present study highlighted the anti-oxidant and the anti-cancer activities of the mucin extracted from E. desertorum snails' mucus that could attract attention to such natural product as a possible source of therapeutic compounds against liver and colon cancers.
\end{abstract}

Keywords: Eremina desertorum- mucin- antioxidant- anti-tumor- CACO-2- HepG-2

Asian Pac J Cancer Prev, 22 (11), 3467-3474

\section{Introduction}

Mollusca is the second largest invertebrate phylum (Sao Mai, 2014; Vinarski et al., 2020) that have a global distribution (Abd-El Azeem et al., 2020). They inhabited freshwater, marine and terrestrial habitat (Neubauer et al., 2015). Members of Mollusca have bioactive compounds that have anti-tumor, antibacterial, and antiviral activities (Rajaganapathy et al., 2000).

Terrestrial snails are widely used in traditional medicine and as food resources because of their high content of protein (Ulagesan and Kim, 2018). These snails secrete mucus secretions called slime (Etim et al., 2016). It serves in protection of the animal from desiccation and infection by microorganisms due to its antimicrobial properties (Nantarat et al., 2019). This mucus consists of a mixture of mucopolysaccharides and glycoproteins (Skingsley et al., 2000), which may contribute to its beneficial pharmacological activities (Gabriel et al., 2011; Abd-El Azeem et al., 2020).

Recently, there is a great interest about using snail mucus and its derivatives like mucin in wound healing, the treatment of skin disorders and muco-adhesive formulations (Hatuikulipi et al., 2016; Ali et al., 2018; Trapella et al., 2018). The slime of Achatina fulica snails could heal wound twice faster than the normal saline solution could do due to its content of glycosaminoglycan (Harti et al., 2016). Helix aspersa slime could ameliorate the experimentally induced colitis and reasoned these activities to its anti-inflammatory and antioxidant properties (Hatuikulipi et al., 2016). Another study on the slime of Helix aspersa maxima snail proved its antitumoral activity against human melanoma cells (Ellijimi et al., 2018). Also, the mucus from Helix aspersa muller has antimicrobial activity and several therapeutic properties, such as skin protection and wound repair due to its content of Helixcomplex; a mucopolysaccaride that contains small amounts of glycolic acid and allantoin (Trapella 2018; Gentili et al., 2020). Other land snails Achatina achatina and Achatina fulica crude mucus extracts have antimicrobial activity (Nantarat et al., 2019).

The desert snails Eremina desertorum (Forsskal, 1775) (Gastropoda: Helicidae) live in sandy deserts and feeds on shrubs (Gabriel et al., 2011; Ali et al., 2016; Ali, 2017). Its mucus is used in wounds, superficial healing and muco adhesive formulations (Adikwu and Okafor,

${ }^{1}$ Department of Immunology, Theodor Bilharz Research Institute, Cairo, Egypt. ${ }^{2}$ Department of Environmental Research and Medical Malacology, Theodor Bilharz Research Institute, Giza, Egypt. ${ }^{3}$ Department of Nucleic Acid Research, Genetic Engineering and Biotechnology Research Institute, City of Scientific Research and Technological Applications, Alexandria, Egypt. *For Correspondence: attashimaa@yahoo.com 


\section{2; Hatuikulipi et al., 2016).}

Oxygen is a highly reactive atom that can be a part of damaging free radical molecules that possess unpaired electron. ROS reactive oxygen species (ROS) is a term which includes all reactive, oxygen-containing molecules (Cheeseman and Slater, 1993). Increased ROS production beyond the enzymatic and non-enzymatic antioxidant systems protective role results in oxidative stress which is a recognized cause of cancer development (Yoshikawa and Naito, 2002). Cancer development passes through three stages: Initiation, promotion, and progression. ROS is involved in all these stages via induction of nucleic acids, proteins, and lipids damage (Katakwar et al., 2016). Total oxidant status (TOS) and total antioxidant status (TAS) are parameters used to measure the general oxidative and antioxidant status of the body, respectively (Wu et al., 2017).

Hepatocellular carcinoma (HCC) is a malignant tumor that originates from hepatocytes and belongs to primary malignant tumors of the liver (Davis et al., 2008). It is the most prevalent malignancy of the liver and stages as the fifth most frequent cancer in men worldwide, and the seventh most dominant in women (Rashed et al., 2020). Colorectal cancer is ranked the fourth most common type of cancer (Rawla et al., 2019). It represents 13\% of all malignant tumors in the gastrointestinal tract. It is the second most common cause of cancer-related death in males and females worldwide. Although there are multiple options available for treating cancers including curative resection, transarterial Chemoembolization, and radioembolization, the recurrence rate of the disease is still high and remains a huge problem (Kumari et al., 2018). Therefore, there is a necessity to investigate and evaluate novel chemo preventive strategies to lower the occurrence of the disease.

The aim of the present study is to investigate the antioxidant and anti-tumor activities of the mucin extracted from Ereminia desertorum snails' mucus against two types of tumor cell lines; CACO-2 and HepG-2 cells.

\section{Materials and Methods}

\section{Handling of Eremina desertorum snails, slime and mucin Animals}

The desert snails Eremina desertorum (Forsskal, 1775) (Gastropoda: Helicidae) were reared in medical malacology lab, Theodor Bilharz research institute. All individuals were cleaned with dechlorinated water to remove excretions on their mantles and shells. Snails were kept in plastic boxes $(16 \times 11 \times 6 \mathrm{~cm})$, temp., $26-28^{\circ} \mathrm{C}$ and kept under high soil moisture ( $80 \%$ relative humidity) and fed on fresh leaves of green lettuce.

\section{Snail slime and mucin extraction}

To have a pure fresh slime samples of the cleaned foot epithelium, snails were washed thoroughly and stimulated by rubbing a sterile wooden rod on its muscular foot, this force the snail to secret more slime; the slime was collected and kept in a sterile container and preserved at $\left(-30^{\circ} \mathrm{C}\right)$ until use.

The slime was macerated in water at $40^{\circ} \mathrm{C}$ for 24 hours.
Fraction containing water-soluble slime was obtained from the procedure of mixing the water twice of the number of samples added to the slime. The supernatant was collected as WSF (Water Soluble Fraction). The slime fraction (mucin fraction) of the WSF was gained using ethanol precipitation technique by mixing the supernatant resulted from water maceration with absolute ethanol in a ratio of 1: 3 , and centrifugation at 2900 r.p.m., for 30 minutes. The precipitation was re-dissolved with Tris $-\mathrm{Cl}$ and finally mucin fraction was obtained (Harti et al., 2016).

\section{Preparation of extract}

Ereminia desertorum snails' mucin was warmed to $37^{\circ} \mathrm{C}$ and filtered using syringe filter $(45 \mu \mathrm{m}$ pore size $)$. The sterile mucin was collected in sterile tube and used immediately.

\section{Cell culture}

\section{Cell line revival and propagation}

HepG-2 and CACO-2 cell lines were obtained from Immunology lab, Theodor Bilharz Research institute. Cells were revived and cultured in RPMI (Gibco) supplemented with $1 \%$ penicillin/streptomycin (Sigma Aldrich), 1\% L glutamine (Sigma Aldrich) and 10\% Fetal bovine serum (Gibco). Tissue culture flasks containing the cells were incubated in 5\% $\mathrm{CO}_{2}$ humidified incubator (Thermo) till reaching confluency.

\section{Applying the mucin to cell lines}

On full confluency, media were discarded and replaced with serum free RPMI supplemented with $0.2 \mu 1 / \mathrm{ml}$ of the Ereminia desertorum snails' mucin. Negative control (cells cultured in RPMI only) and positive control (cells cultured in RPMI and lead nitrate $50 \mathrm{mM} / \mathrm{ml}$ ) were included. Flasks were incubated overnight in $5 \% \mathrm{CO}_{2}$ incubator.

\section{Cell trypsinization}

Media were collected for measuring the anti-oxidant markers and flasks were washed with PBS (Gibco) and cells were trypsinized by $0.25 \%$ Trypsin-EDTA solution (Sigma Aldrich). Flasks were incubated at $37^{\circ} \mathrm{C}$ for $2 \mathrm{~min}$. Trypsin was deactivated by adding equal volume of culture media and cells were collected, washed with PBS twice by centrifugation and subjected to gene analysis by RT-PCR.

\section{Gene expression analysis}

\section{RNA extraction}

RNA was isolated using the RNeasy Kit (Qiagen, Chatsworth, CA) according to the manufacturer's instructions. One microgram of cellular RNA was reverse transcribed into cDNA using SuperScript II reverse transcriptase and random hexamer primers (Invitrogen Life Technologies, USA).

\section{$R T-P C R$}

The PCR reaction was carried out in a volume of 10 $\mu 1$ in a mixture that contained appropriate sense- and anti-sense primers and a probe in TaqMan Universal PCR Master Mixture (Applied Biosystems, Foster City, California). We used the Assays-on-DemandTM Gene Expression products, which consist of a 20x mix 
of unlabeled PCR primers and TaqMan MGB probe (FAMTM dye-labeled). These assays are designed for the detection and quantification of specific human genetic sequences in RNA samples converted to cDNA. The primers used are illustrated in Table 1. Real-time PCR amplification and data analysis were performed using the A7500 Fast Real-Time PCR System (Applied Biosystems). Each sample was assayed in duplicate in a MicroAmp optical 96-well plate. The thermo-cycling condition consisted of 2 minutes at $50^{\circ} \mathrm{C}$ and $10 \mathrm{~min}$ incubations at $95^{\circ} \mathrm{C}$, followed by 40 two-temperature cycles of 15 seconds at $95^{\circ} \mathrm{C}$ and $1 \mathrm{~min}$ at $60^{\circ} \mathrm{C}$. Gene expression was normalized to internal controls and fold changes were calculated using the relative quantification $\operatorname{method}\left(2^{-\Delta \Delta \mathrm{Cq}}\right)$.

\section{Statistical analysis}

One Way ANOVA was used to test the effect of the extract on the measured parameters of tested cells in comparison to the other two groups.

\section{Results}

Oxidative markers

The antioxidative markers in mucin extract treatedculture media of HepG-2 cells showed high significant increase in the activity of catalase, SOD, GSH and total antioxidants as compared with their levels in media of untreated cells ( $\mathrm{p}$ value $<0.001$ ) (Figure 1).

The antioxidative markers in mucin extract treated-culture media of CACO-2 cells showed high significant increase in the activity of catalase, SOD, GSH and total antioxidants as compared with media of untreated cells ( $p$ value $<0.001$ ). While SOD didn't show a significant difference when compared to the untreated cells (Figure 2).
Gene expression analysis

Antioxidant genetic markers

Gene expression levels ( $2^{\wedge}$-ddet $)$ of Antioxidant markers in HepG-2 cells; GSTA-1, catalase, SOD, and GPx showed increased expression in cells treated with the mucin extract by $(2.46,2.98,4.62$ and 3.40), respectively when compared to the cells treated with lead nitrate $(0.40,0.32$, 0.32 and 0.31 ). Gene expression levels in untreated control cell group equal (1) in data analysis and calculation. That means that the antioxidant genetic markers were up-regulated in HepG-2 cells by treatment with mucin extract and controversial, down-regulated by treatment with lead nitrate (Figure 3).

On the other hand, gene expression levels $\left(2^{\wedge}\right.$-ddct $)$ of Antioxidant markers in CaCO-2 cells; GSTA-1, catalase, SOD, and GPx showed increased expression in cells treated with the mucin extract by $(2.92,4.35,4.51$ and $1.89)$, respectively when compared to the cells treated with lead nitrate $(0.26,0.39,0.56$ and 0.59$)$. Gene expression levels in untreated control cell group equal (1) in data analysis and calculation. That means that the antioxidant genetic markers were up-regulated in $\mathrm{CaCO}-2$ cells by treatment with mucin extract and controversial, downregulated by treatment with lead nitrate (Figure 4).

\section{Tumor suppression genes analysis}

Gene expression levels ( $2^{\wedge}$-ddct $)$ of tumor suppression genes in HepG-2 cells; p53, Rb, APC, and PTEN showed increased expression in cells treated with the mucin extract by (43.2, 43.6, 45.4 and 39.6), respectively when compared to the cells treated with lead nitrate (24.2, $17.9,12.8$ and 13.9). Gene expression levels in untreated control cell group equal (1) in data analysis and calculation (Figure 5).

On the other hand, gene expression levels $\left(2^{\wedge}\right.$-ddet $)$ of tumor suppression genes in $\mathrm{CaCO}_{2}$ cells; p53, $\mathrm{Rb}, \mathrm{APC}$,

Table 1. Primers Sequences for RT-PCR

\begin{tabular}{|c|c|c|c|}
\hline Symbol & Gene & Primer sequence & Reference \\
\hline \multirow[t]{2}{*}{ P53 } & \multirow[t]{2}{*}{ Tumor protein $\mathrm{p} 53$} & F: 5'-ATGTTTTGCCAACTGGCCAAG-3' & \multirow[t]{2}{*}{ Mitupatum et al. (2016) } \\
\hline & & R: 5'-TGAGCAGCGCTCATGGTG-3' & \\
\hline \multirow[t]{2}{*}{$\mathrm{Rb}$} & \multirow[t]{2}{*}{ retinoblastoma gene } & F: 5'-ATGCCCCAGAACCCTTGTATC-3' & \multirow[t]{2}{*}{ Wu et al. (2017) } \\
\hline & & R: 5'-GCCCATAGCCTTCCTTCTGAT-3' & \\
\hline \multirow[t]{2}{*}{ APC } & \multirow[t]{2}{*}{ Adenomatous polyposis coli } & F: 5'- ACCTCATCATTACACGCCTATT -3' & \multirow[t]{2}{*}{ Zhang et al. (2015) } \\
\hline & & R: 5'- CCTTATTTTCTTTTGCCTTTCT-3' & \\
\hline \multirow[t]{2}{*}{ PTEN } & \multirow{2}{*}{$\begin{array}{l}\text { Phosphatase and tensin homolog } \\
\text { protein }\end{array}$} & 5'-ACAGGC-TCCCAGACATGACA-3' & \multirow[t]{2}{*}{ Ma et al. (2005) } \\
\hline & & 5'- TCAG-ACTTTTGTAATTTGTGTATG-3' & \\
\hline \multirow[t]{2}{*}{ GSTA1 } & \multirow{2}{*}{$\begin{array}{l}\text { Glutathione S-Transferase Alpha } \\
1\end{array}$} & F: 5'-AGCCGGGCTGACATTCATCT-3' & \multirow[t]{2}{*}{ Razali et al. (2010) } \\
\hline & & R: 5'-TGGCCTCCATGACTGCGTTA-3' & \\
\hline \multirow[t]{2}{*}{ CAT } & \multirow[t]{2}{*}{ Catalase } & F: 5'-CCAGATCAGTAGCGTGGCACG-3' & \multirow[t]{2}{*}{ Kampkötter et al. (2007) } \\
\hline & & R:5'-CATAGCGTGCGGTTTGCTGTGC-3' & \\
\hline \multirow[t]{2}{*}{ SOD } & \multirow[t]{2}{*}{ Super oxide dismutase } & F: 5'-ACTGGTGGTCCATGAAAAAGC-3' & \multirow[t]{2}{*}{ Zhang et al. (2015) } \\
\hline & & R: 5'-AACGACTTCCAGCGTTTCCT-3' & \\
\hline \multirow[t]{2}{*}{ GPx } & \multirow[t]{2}{*}{ Glutathione peroxidase } & F: 5'- CACAACGGTGCGGGACTA -3' & \multirow[t]{2}{*}{ Chen et al. (2016) } \\
\hline & & R: 5'- CATTGCGACACACTGGAGAC -3' & \\
\hline \multirow[t]{2}{*}{$\beta$-actin } & Beta-actin & F: 5-TCCCTGGAGAAGAGCTACG-3' & \multirow[t]{2}{*}{ Sharula and Zhongjun. (2017) } \\
\hline & (reference gene) & R: 5-GTAGTTTCGTGGATGCCACA-3' & \\
\hline
\end{tabular}



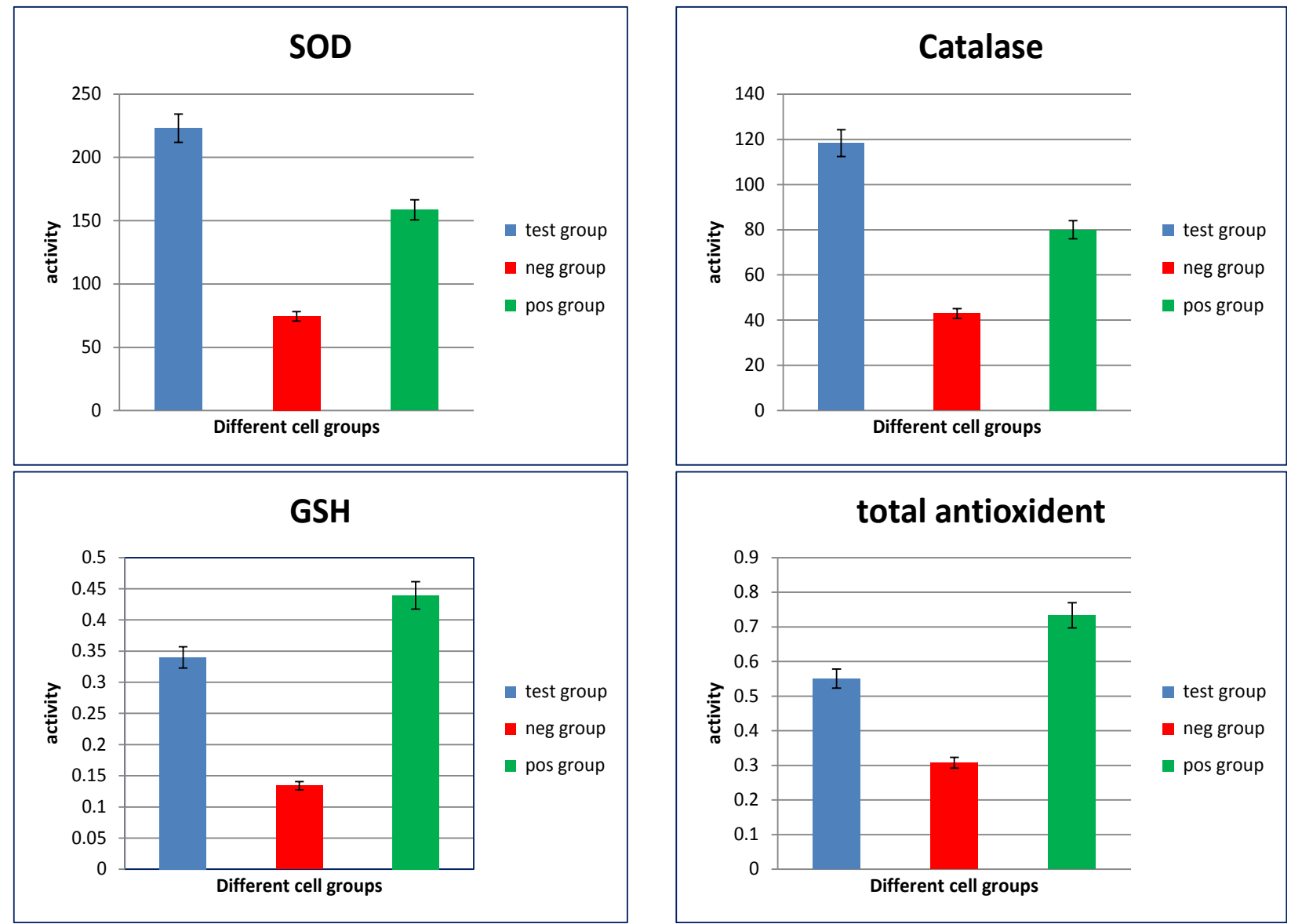

Figure 1. Oxidative Stress Markers Measured in Culture Media of Different HepG-2 Cell GAroups. SOD, superoxide dismutase; GSH, reduced glutathione
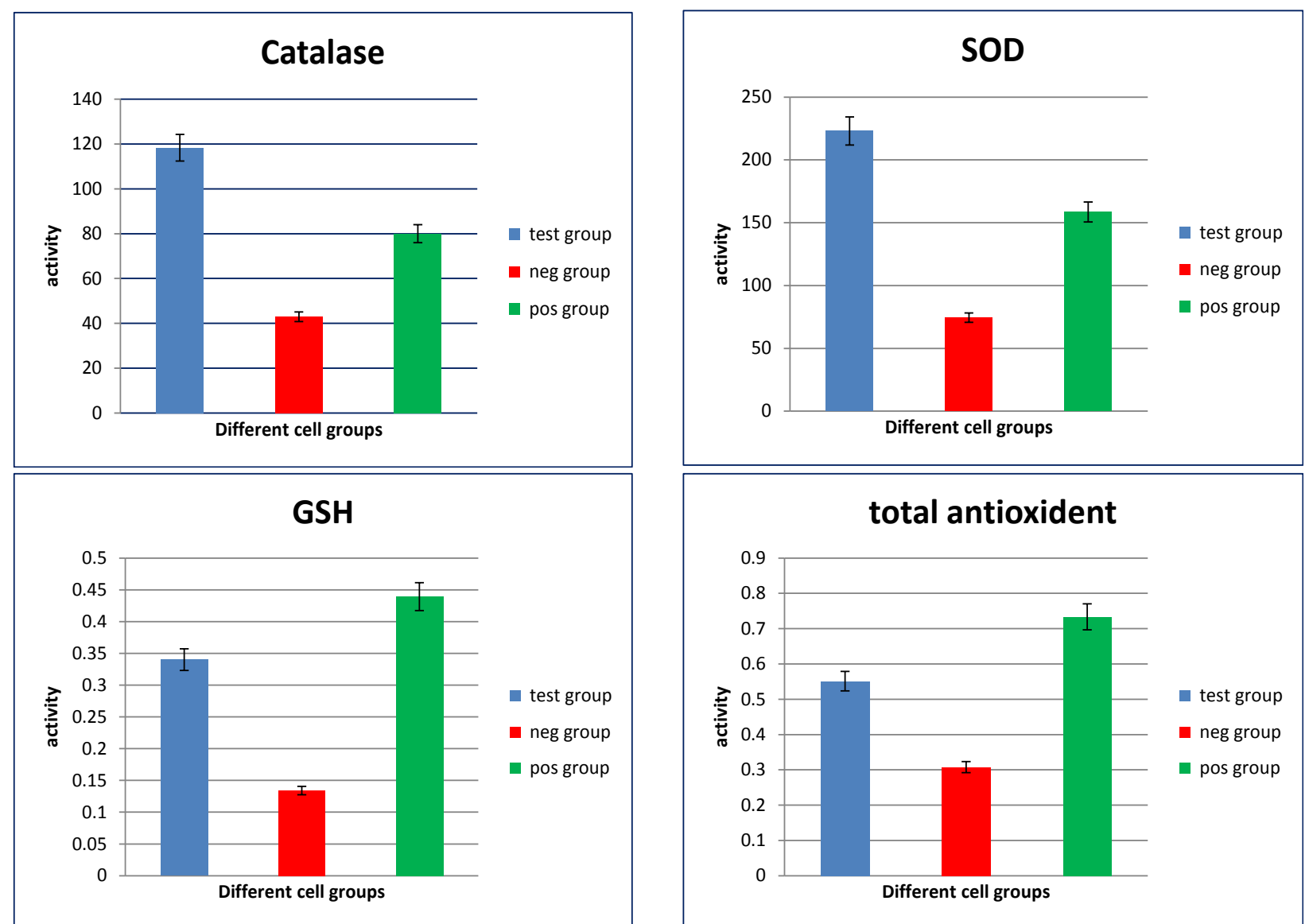

Figure 2. Oxidative Stress Markers Measured in Culture Media of Different $\mathrm{CACO}_{2}$ Cell Groups. SOD, superoxide dismutase; GSH, reduced glutathione 


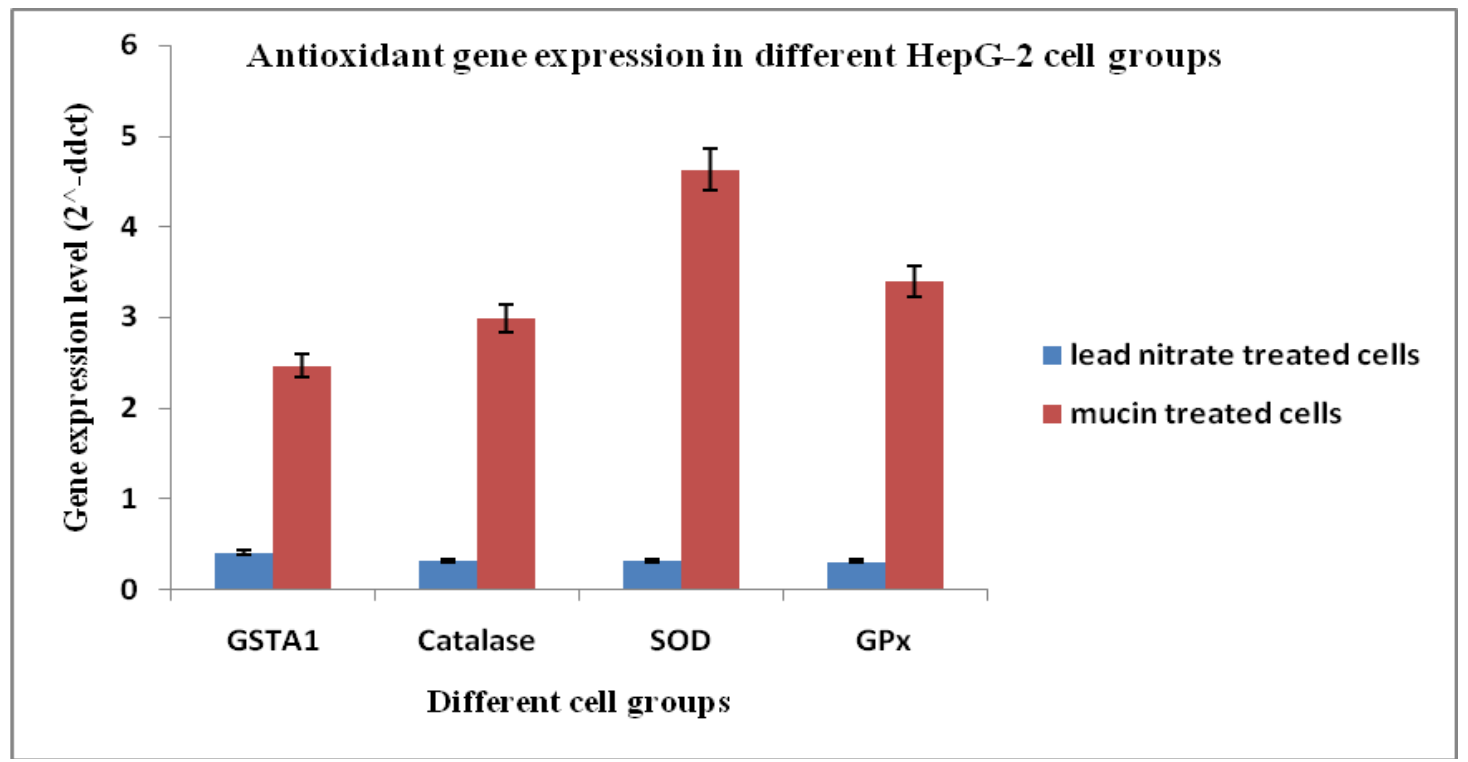

Figure 3. Antioxidant Gene Expression Levels in Different HepG-2 Cell Groups. SOD, Superoxide dismutase; GPx, Glutathione peroxidase; GSTA1, Glutathione S-transferase A1

and PTEN showed increased expression in cells treated with the mucin extract by $(31.5,26.2,34.8$ and 31.0$)$, respectively when compared to the cells treated with lead nitrate $(10.7,6.5,9.6$ and 6.0). Gene expression levels in untreated control cell group equal (1) in data analysis and calculation (Figure 6).

\section{Discussion}

Terrestrial snail mucus consists of a mixture of mucopolysaccharides and glycoproteins that have many pharmacological activities (Abd-El Azeem et al., 2020). These bioactive components have cytotoxic, anti-inflammatory, antimicrobial, and anti-tumor activities (Anand and Edward, 2002). They are also involved in variety skin care compositions as they have anti-aging properties (Dolashka et al., 2015).
Oxidative stress can be involved in the development of chronic and degenerative illness such as cancer, neurodegenerative diseases, autoimmune disorders, and rheumatoid arthritis (Pham-Huy et al., 2008). Reactive oxygen species (ROS) are the main cause of the oxidative stress in the body (Rezaie et al., 2007). To maintain the balance in the body, the endogenous antioxidant system scavenged ROS and the free radicals (Halliwell, 2006). The endogenous anti oxidative enzymes such as superoxide dismutase (SOD), catalase (CAT) and glutathione peroxidase (GPx) are able to protect the liver against oxidative damage and SOD and SOD catalyzes the dismutation of the superoxide anion radical $(\mathrm{O} 2)$ to oxygen and hydrogen peroxide $\left(\mathrm{H}_{2} \mathrm{O}_{2}\right) . \mathrm{H}_{2} \mathrm{O}_{2}$ may then be converted into water by CAT. By contrast, GPx is able to protect the cell against oxidative stress via the reduction of $\mathrm{H}_{2} \mathrm{O}_{2}$ and lipid peroxides, using glutathione

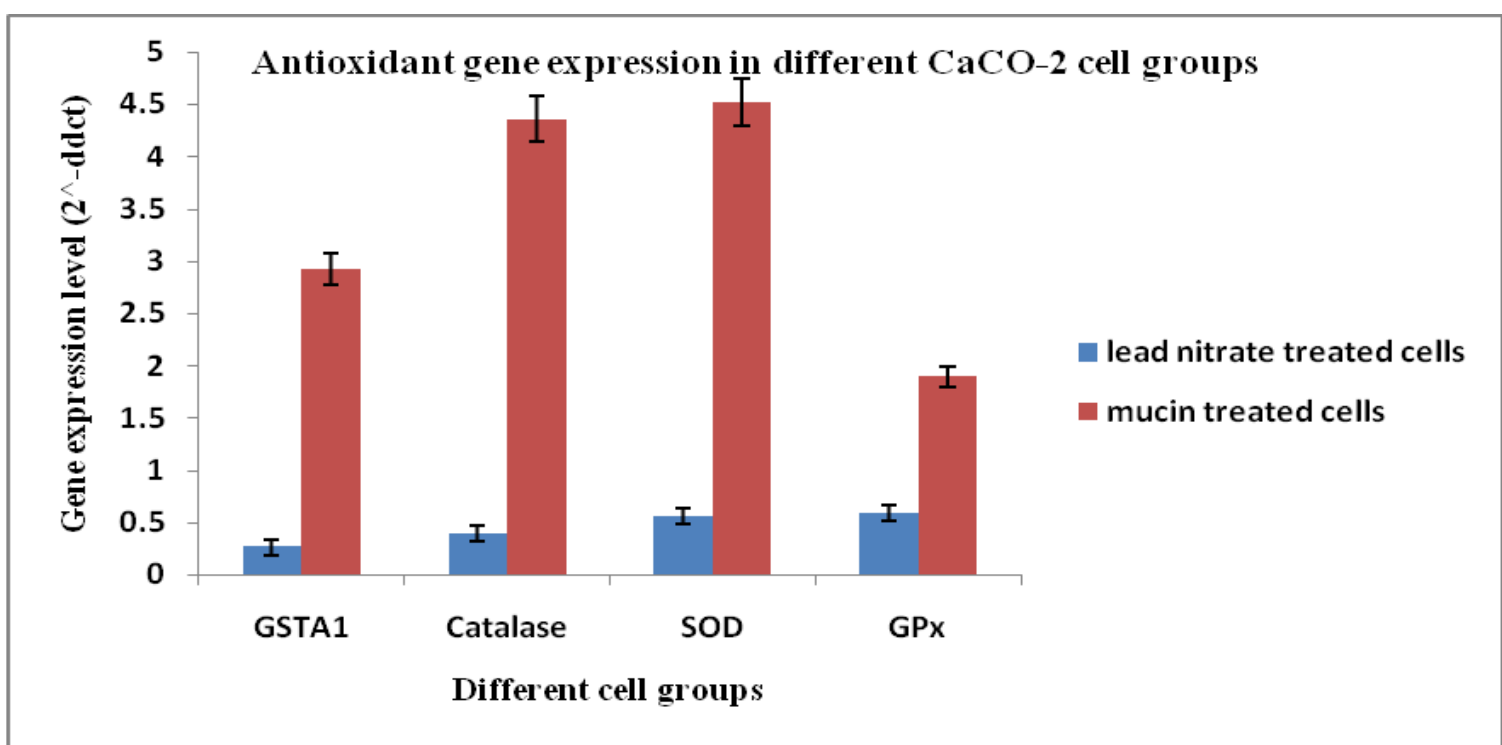

Figure 4. Antioxidant Gene Expression Levels in Different $\mathrm{CaCO}_{2}$ Cell Groups. SOD, Superoxide dismutase; GPx, Glutathione peroxidase; GSTA1, Glutathione S-transferase A1 


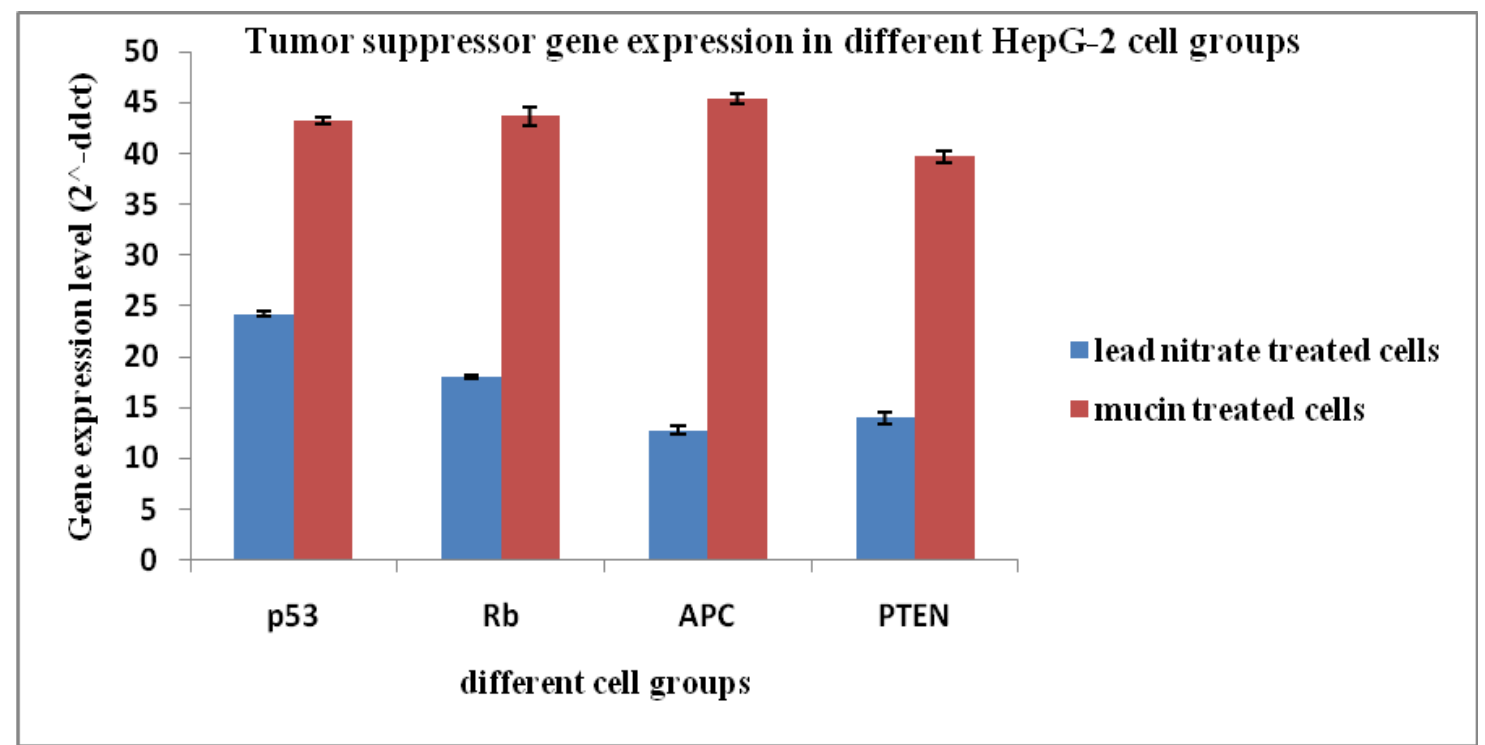

Figure 5. Tumor Suppression Genes Levels in Different HepG-2 Cell Groups. p53, Tumor protein p53; Rb, retinoblastoma gene; APC, Adenomatous polyposis coli; PTEN, Phosphatase and tensin homolog protein

as an electron donor (Kumar et al., 2012). Glutathione S-transferases (GSTs) are involved in the detoxification of xenobiotics such as toxins and carcinogens (Eaton and Bammler, 1999).

The main function of the antioxidants is depending on its reducing power of the oxidative damage (Bashir et al., 2015). Many antioxidants compounds are present in natural product such as snail hemolymph (Shittu et al., 2015), and mucus (Gabriel et al., 2011).

The present results revealed that the culture media of HepG-2 cells treated with the extract have high significant increased levels of catalase, SOD, GSH and total antioxidants. Also, there were high significant increased levels of catalase, GSH and total antioxidants in culture media of $\mathrm{CACO}_{2}$ cells treated with extract. While SOD level didn't show significant difference between the treated and the untreated cells. Also, the present investigation confirmed that antioxidant genetic markers were up-regulated in HepG-2 cells by treatment with mucin extract. Where Gene expression levels ( $2^{\wedge}$-ddct $)$ of the antioxidant markers; GSTA-1, catalase, SOD, and GPx showed increased expression in media of HepG2 cells treated with the mucin extract. Also, antioxidant genetic markers were up-regulated in CACO- 2 cells by treatment with mucin extract.

These antioxidant properties were reported and confirmed in Cornu aspersum mucus due to the presence of allantoin that has antioxidant activities (Kostadinova et al., 2018). Also, Brieva et al., (2008) found that slime from Helix aspersa garden snail contains antioxidant superoxide dismutase and glutathione-s-transferase activity. Chen et al., (2019) stated that pretreatment with Ligustrum robustum polyphenol extract lead to cytoprotective effect against Hydrogen Peroxide-Induced Oxidative Stress, where it decreased ROS level, and maintaining the endogenous antioxidant system through increasing of

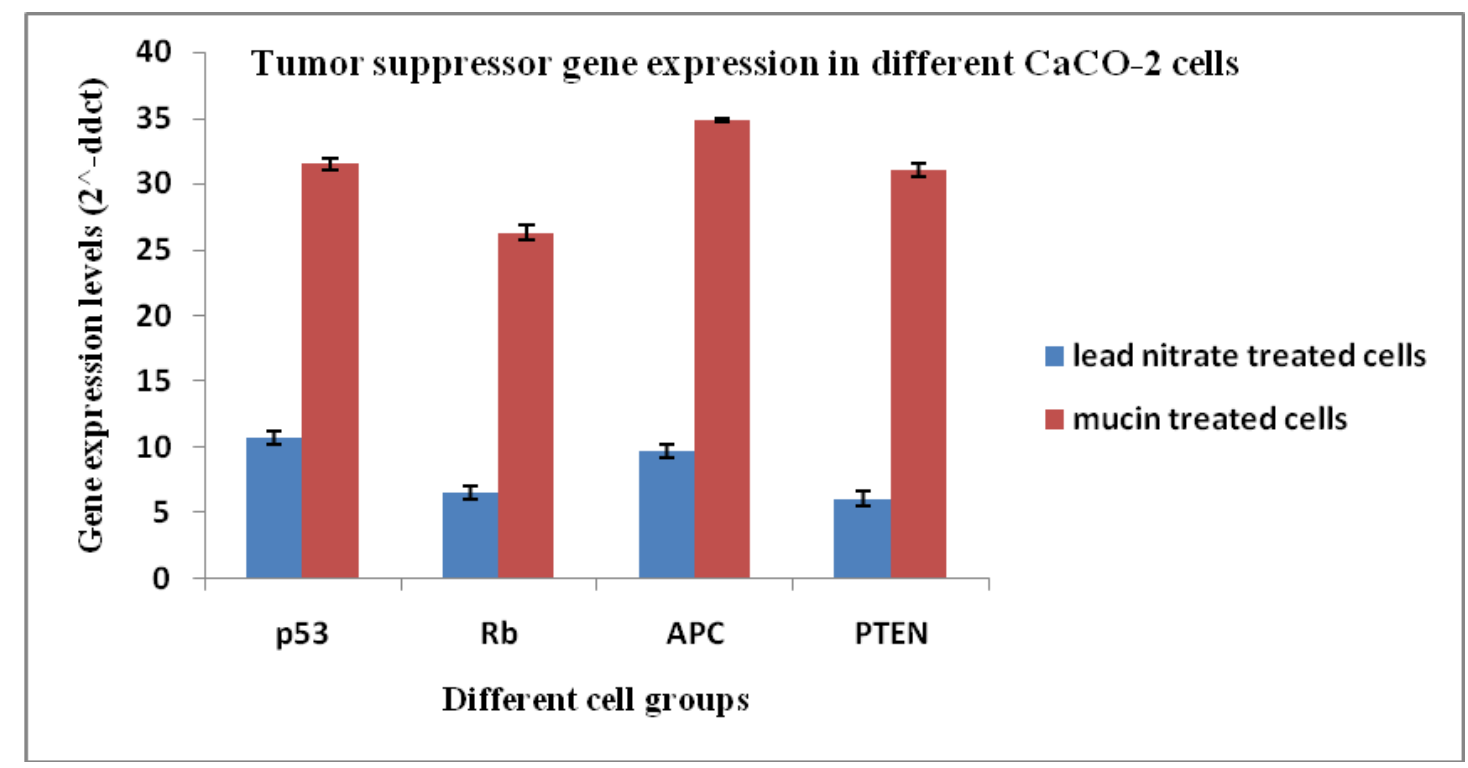

Figure 6. Tumor Suppression Genes Levels in Different CACO, Cell Groups. p53, Tumor protein p53; Rb, retinoblastoma gene; APC, Adenomatous polyposis coli; PTEN, Phosphatase and tensin homolog protein 
SOD, CAT, GSH-Px, and GR activities compared to the $\mathrm{H}_{2} \mathrm{O}_{2}$ group. It could be attributed that the high dosage extracts may exert antioxidant activities by directly scavenging free radicals and its reducing capacity.

The main objective of treating cancer is to promote the death of cancer cells without causing damage to normal cells (Gerl and Vaux, 2005). P53 protein is one of the tumor suppressors that help in the removal of DNA-damaged cells and in arresting the cell cycle (Chiang et al., 2014). Another tumor suppressor is the retinoblastoma protein (RB) (Agarwal et al., 1998). It regulates the cell proliferation and suppresses cancer growth (Goodrich, 2006; Ebata et al., 2016). The adenomatous polyposis coli (APC) gene is a key tumor suppressor gene that is involved in cell adhesion and migration, organization of the actin and microtubule networks, spindle formation and chromosome segregation (Aghabozorgi et al., 2019). Also, phosphatase and tensin homolog deleted on chromosome ten (PTEN) is the key negative regulator of the phosphatidylinositol 3-kinase (PI3K) signaling pathway that promotes cell survival and proliferation and is frequently deregulated in various human cancers (Stambolic et al., 1998). Mutations of the PTEN gene arise during cancer progression (Ali et al., 1999).

The present results showed that gene expression levels of p53, Rb, APC, and PTEN were increased in both HepG-2 and CACO-2 cells treated with the mucin extract. These results are in good accordance with Teerasak et al., (2016) who confirmed the presence of two fractions of proteins in the African snail Achatina fulica mucus that can decrease the viability of breast cancer cells (MCF-7). Also, the mucus of Actinia equine showed cytotoxic effect on human erythromyeloid leukemia-derived cells (K592) (Stabili et al., 2015). El Ouar et al., (2017) showed that the extracts from tissues of Helix Aspersa Müller possessed anticancer activity against breast cancer cells (Hs578T).

Conclusively, the present study highlights the antioxidative and the anti-cancer activities of the mucin extracted from E. desertorum snails' mucus against two types of tumor cells; CACO-2 and HepG2 cells. This could be helpful for the production of a natural cancer therapy.

\section{Author Contribution Statement}

None.

\section{Acknowledgments}

None.

\section{References}

Abd El Azeem H, Osman G, El-sabbagh S, Sheir S (2020). Antibacterial activity of some terrestrial gastropods from Egypt against Staphylococcus Aureus and Escherichia Coli. Egy J Zoology, 74, 1-12.

Adikwu M, Okafor J (2012). Application of the animal products mucin and honey in wound healing: A Pathophysiology, Therapeutics and Pharmaceutical Review. Afr J Pharm Sci Pharm, 3, 1-17.

Agarwal M, Taylor W, Chernov M, et al (1998). The p53 network. J Biol Chem, 273, 1-4.

Aghabozorgi A, Bahreyni A, Soleimani A, et al (2019). Role of adenomatous polyposis coli (APC) gene mutations in the pathogenesis of colorectal cancer; current status and perspectives. Biochimie, 157, 64-71.

Ali I, Schriml L, Dean M (1999). Mutational spectra of PTEN/ MMAC1 gene: A tumor suppressor with lipid phosphatase activity. $J$ Natl Cancer Inst, 91, 1922-32.

Ali M, Ashari M, Wijaya S, Lestari E, Wijayanti R (2018). Evaluation of wound healing effect of eel mucus ointment (Belutidine) in mice by incision model. $J$ Nat Remedies, 18, 1-9.

Ali R (2017). Morphological and anatomical characteristics of the two Taxa Eremina desertorum (Forskål, 1775) and Eremina desertorum irregularis (Férussac, 1821) (Gastropoda: Helicidae) of the Northern Deserts of Egypt Article. Egy Acd J Biol Sci, 9, 43-54.

Ali R, Neiber M, Walther F, Hausdorf B (2016). Morphological and genetic differentiation of Eremina desertorum (Gastropoda, Pulmonata, Helicidae) in Egypt. Roy Swed Acad Sci, 45, 48-61.

Anand T, Edward J (2002). Antimicrobial activity in the tissue extracts of five species of cowries cypraea spp. (Mollusca: Gastropoda) and an ascidian didemnum psammathodes (Tunicata: Didemnidae). Indian J Mar Sci, 31, 239-42.

Bashir N, Manoharan V, Prabu S (2015). Oxidative stress induced by cadmium in the plasma, erythrocytes and lymphocytes of rats: Attenuation by grape seed proanthocyanidins. Hum Exp Toxicol, 35, 1-21

Brieva A, Philips N, Tejedor R, et al (2008). Molecular basis for the regenerative properties of a secretion of the Mollusk Cryptomphalus aspersa. Skin Pharmacol Physiol, 21, 15-22.

Cheeseman K, Slater T (1993). An introduction to free radial biochemistry. Br Med Bull, 49, 48193.

Chen J, He F, Liu S, et al (2019). Cytoprotective effect of Ligustrum robustum polyphenol extract against hydrogen peroxide. Evid Compl Altern Med, 2019, 1-8.

Chen W, Shaw L, Chang P, et al (2016). Hepatoprotective effect of resveratrol against ethanol-induced oxidative stress through induction. Exp Therap Med, 11, 1231-8.

Chiang K, Tsui K, Chung L, et al (2014). Cisplatin modulates B-cell translocation gene 2 to attenuate cell proliferation of prostate carcinoma cells in both p53- dependent and p53independent pathways. Sci Rep, 4, 5511-21.

Davis G, Dempster J, Meler J, et al (2008). Hepatocellular carcinoma: management of an increasingly common problem. Proc Bayl Univ Med Cent, 21, 266-80.

Dolashka P, Dolashki A, Velkova L, et al (2015). Bioactive compounds isolated from garden snails. J Bio Sci Biotechnol, 2015, 147-55

Eaton D, Bammler T (1999). Concise review of the glutathione S-transferases and their significance to toxicology. Toxicol Sci, 49, 156-64.

Ebata T, Hirata H, Kawauchi K (2016). Functions of the tumor suppressors p53 and $\mathrm{Rb}$ in actin cytoskeleton remodeling. Cell Mol Mechan Heal Dis, 2016, 1-10.

El Ouar I, Braicu C, Naimi D, Irimie A, Berindan-Neagoe I (2017): Effect of Helix aspersa extract on TNF $\alpha, N F-\kappa B$ and some tumor suppressor genes in breast cancer cell line Hs578T. Pharmacogn Mag, 13, 281-5.

Ellijimi C, Ben Hammouda M, Othman H, et al (2018). Helix aspersa maxima mucus exhibits antimelanogenic and antitumoral effects against melanoma cells. Biomed Pharmacother, 101, 871-80.

Etim L, Aleruchi C, Obande G (2016). Antibacterial properties of Snail Mucus on bacteria isolated from patients with wound infection. Br Microbiol Res J, 11, 1-9. 
Gabriel UI, Mirela S, Ionel J (2011). Quantification of mucoproteins (glycoproteins) from snails mucus, Helix aspersa and Helix Pomatia. J Agroaliment Process Technol, 17, 410-13.

Gentili V, Bortolotti D, Benedusi M, et al (2020). HelixComplex snail mucus as a potential technology against $\mathrm{O} 3$ induced skin damage. PLoS One, 15, e0229613.

Gerl R, Vaux DL (2005). Apoptosis in the development and treatment of cancer. Carcinogenesis, 26, 263-70

Goodrich DW (2006). The retinoblastoma tumorsuppressor gene, the exception that proves the rule. Oncogene, 25, 5233-43.

Halliwell B (2006). Reactive species and antioxidants. Redox biology is a fundamental theme of aerobic life. Plant Physiol, 141, 312-22.

Harti A, Sulisetyawati S, Murharyati A, Oktariani M, Wijayanti I (2016). The effectiveness of snail slime and chitosan in wound healing. Int. J Pharma Med Biol Sci, 5, 76-80.

Hatuikulipi T, Kouachi M, Bouchetob L, et al (2016). Preventive effect of Helix aspersa slime against experimentally chemoinduced colitis in rat. Der Pharm Lett, 8, 200-6.

Kampkötter A, Wiegand C, Timpel C, et al (2007). Increased expression of catalase in human hepatoma cells by the Soy Isoflavone, Daidzein. Bas Clin Pharmacol Toxicol, 102, 437-42.

Katakwar P, Metgud R, Naik S, Mittal R (2016). Oxidative stress marker in the oral cavity: A review. J Cancer Res Ther, 12, 43847.

Kostadinova N, Voynikov Y, Dolashki A, et al (2018). Antioxidative screening of fractions from the mucus of garden snail Cornu aspersum. Bulg Chem Comm, 50, 176- 83.

Kumar M, Sharma V, Sehgal A, Jain M (2012). Protective effects of green and white tea against benzo(a)pyrene induced oxidative stress and DNA damage in murine model. Nutr Cancer, 64, 300-6.

Kumari R, Sahu M, Tripathy A, Uthansingh K, Behera M(2018). Hepatocellular carcinoma treatment: hurdles, advances and prospects. Hepat Oncol, 5(2):HEP08. Published 2018 Sep 28. doi:10.2217/hep-2018-0002.

Ma D, Xu Z, Liang Y, et al (2005). Down-regulation of PTEN expression due to loss of promoter activity in human hepatocellular carcinoma cell lines. World J Gastroenterol, 11, 4472-7.

Mitupatum T, Aree K, Kittisenachai S, et al (2016). mRNA expression of Bax, Bcl-2, p53, Cathepsin B, Caspase-3 and Caspase-9 in the HepG2 cell line following induction by a novel monoclonal Ab Hep88 mAb: Cross-Talk for Paraptosis and Apoptosis. Asian Pac J Cancer Prev, 17, 703-12.

Nantarat N, Tragoolpua Y, Gunama P (2019). Antibacterial activity of the Mucus Extract from the Giant African Snail (Lissachatina fulica) and Golden Apple Snail (Pomacea canaliculata) against pathogenic bacteria causing skin diseases. Trop Nat Hist, 19, 103-12.

Neubauer T, Harzhauser M, Georgopoulou E, Kroh A, Mandic O (2015). Tectonics, climate, and the rise and demise of continental aquatic species richness hotspots. Proc Natl Acad Sci U S A, 112, 11478-83

Pham-Huy L, He H, Pham-Huy C (2008). Int free radicals, antioxidants in disease and health. J Biomed Sci, 4, 89-96.

Rajaganapathy J, Thyagarajam SP, Edward JK (2000). Study on cephalopod's ink for anti-retroviral activity. Indian $J$ Exp Biol, 38, 519-20

Rashed W, Kandeil M, Mahmoud M, Ezzat S (2020). Hepatocellular Carcinoma (HCC) in Egypt: A comprehensive overview. J Egypt Natl Cancer Inst, 32, 5.

Rawla P, Sunkara T, Barsouk (2019). Epidemiology of colorectal cancer: incidence, mortality, survival, and risk factors. Prz
Gastroenterol, 14, 89-103.

Razali N, Aziz A, Junit S (2010). Gene expression profiles in human HepG2 cells treated with extracts of the Tamarindus indica fruit pulp. Genes Nutr, 5, 331-41.

Rezaie A, Parker R, Abdollahi M (2007). Oxidative stress and pathogenesis of inflammatory bowel disease: an epiphenomenon or the cause?. Dig Dis Sci, 52, 2015-21.

Sao Mai D (2014). Shellfish (Molluscs and Crustacea): Characteristics of the Groups, in: Encyclopedia of Food Microbiology: Second Edition. Elsevier Inc., pp 376-88.

Sharula, Zhongjun Wu (2017). Regulation of apoptosis by SYB in HepG2 liver cancer cells is mediated by the P53/Caspase 9 Axis. Anti-Cancer Agen Med Chem, 17, 941-7.

Shittu O, Lawal B, Haruna G,et al (2015). Hepato-curative effects of methanol extract from Nigeria bee propolis in carbon tetrachloride (CCL4) Intoxicated rat. Eur $J$ Biotechnol Biosci, 3, 12-6.

Skingsley D, White A, Weston A (2000). Analysis of Pulmonate Mucus by infrared spectroscopy. J Molluscan Stud, 66, 363-72.

Stabili L, Schirosi R, Parisi MG, Piraino S, Cammarata M (2015). The mucus of Actinia equina (Anthozoa, Cnidaria): An unexplored resource for potential applicative purposes. Mar Drugs, 13, 5276-96.

Stambolic V, Suzuki A, de la Pompa JL, et al. (1998). Negative regulation of PKB/Akt-dependent cell survival by the tumor suppressor PTEN. Cell, 95, 29-39.

Teerasak E, Thongararm P, Roytrakul S, Meesuk L, Chumnanpuen $P$ (2016). Prediction of anticancer peptides against MCF-7 breast cancer cells from the peptidomes of Achatina fulica mucus fractions. Comput Struct Biotechnol J, 14, 49-57.

Trapella C, Rizzo R, Gallo S, et al. (2018). HelixComplex snail mucus exhibits pro-survival, proliferative and pro-migration effects on mammalian fibroblasts. Sci Rep, 8, 1-10.

Ulagesan S, Kim H (2018). Antibacterial and antifungal activities of proteins extracted from seven different snails. Appl Sci, 8, 1362-71.

Vinarski M, Bolotov I, Aksenova O, et al (2020). Freshwater mollusca of the circumpolar arctic: A review on their taxonomy, diversity and biogeography. Hydrobiologia, https://doi.org/10.1007/s10750-020-04270-6.

Wu R, Feng J, Yang Y, et al (2017). Significance of serum total oxidant/antioxidant status in patients with colorectal cancer. PLoS One, 12, e 0170003.

Wu S, Wang L, Ren X, et al (2017). Involvement of retinoblastomaassociated protein 48 during photodynamic therapy of cervical cancer cells. Mol Med Rep, 15, 1393-1400.

Yoshikawa T, Naito Y (2002). What is oxidative stress?. J Japan Med Assoc, 45, 2716.

Zhang S, Xue J, Zheng J, et al (2015). The superoxide dismutase 1 (SOD1) 3'UTR maintains high expression of the SOD1 gene in cancer cells: the involvement of the RNA binding protein AUF-1. Free Radic Biol Med, 85, 33-44.

Zhang Z, Zhang Y, Sun X, Ma X, Chen Z (2015). microRNA146a inhibits cancer metastasis by downregulating VEGF through dual pathways in hepatocellular carcinoma. Mol Cancer, 14, 2-15.

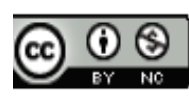

This work is licensed under a Creative Commons AttributionNon Commercial 4.0 International License. 